\title{
HUMANITY AND CREATUREHOOD
}

In Tragic Wisdom and Beyond, published toward the end of his life, Gabriel Marcel ends his discussion of authentic humanism with a striking remark: "At the present moment," he says, "for a philosopher who is conscious of his responsibilities ...there is probably no more pressing task than finding fundamental existential assurances which are constitutive of being truly human in the image of God."1

The language here is somewhat different from what he normally employs, but there is no mistaking its seriousness. Lived atheism, he insists, can only open the way to "despair" and be a "path to death." While more fervent and overtly "religious" than his customary style, the passage nevertheless enunciates a view to which he had long been committed: human existence, to be fully authentic, must be open to God, and philosophical thought, to be fully authentic, must bear witness to this openness.

It would not be difficult to find repeated instances of this position throughout his writings. In the last few pages of his remarkable essay on "The Mystery of the Family" in Homo Viator, he says that "In the last analysis it is on this elementary yet generally misunderstood notion of the state of a creature, the condition of a creature, that we must place the decisive accent." 2 In the concluding chapter of The Mystery of Being he stresses the "fundamental fact that our condition is that of creatures, who can never cease to be such, and who are compelled to think of ourselves only in this perspective."3 And in Men Against Humanity he warns against the dangerous consequences which await "so soon as man denies to

1 Tragic Wisdom and Beyond, tr. Stephen Jolin and Peter McCormick, (Evanston, III., Northwestern Univ. Press, 1973), p. 44.

2 Homo Viator, tr. Emma Crauford, (Chicago, Henry Regnery 195I), p. 95.

3 The Mystery of Being, vol. II, tr. René Hague, (Chicago, Henry Regnery, 1951), pp. 172/3. 
It would be wrong to regard such statements as mere concessions to the language of conventional piety or as lapses into sentimentalism. On the contrary, they are distillations of the issue upon which philosophy turns. The question of whether or not the human self can be understood apart from a relation to a transcendent is not just one among others, which might be of interest to certain groups of thinkers. If philosophy is the prosecution of the human search for self-understanding, it is idle to pretend that this central question does not pervade every aspect of the search. Certainly not all of what has passed for philosophy in the twentieth century has felt it incumbent upon itself to address or even to pay attention to this question; many philosophers have either wanted to get on with other business or have declared the question out of court as a pleader with no standing. But this has not rendered either their thought or their lives immune from the consequences of their own refusal. Marcel even saw a connection between the Nietzschean proclamation "God is dead!" and the spreading fear in the practical order that man is in his death throes. 5 The fear to which he alludes was no doubt generated in large part by the dread felt over the standing threat of mutual annihilation which seemed to hang over the human race in the shadow of the nuclear bomb and the cold war. But in our time a connection could also be drawn between the subjectivizing of the issues of God and morality and the cultural disintegration which it is no longer possible to deny as threatening the stability of western society - a disintegration which was already in the forefront of Marcel's concern.

Yet from another standpoint the reader of Marcel might be a little puzzled by his use of the term "creaturehood" to convey his view of the matter. First, it seems more unabashedly "religious" than his ordinary way of speaking and might be taken to give religious belief a determinative role in philosophy. While Marcel is undeniably a

${ }^{4}$ Men Against Humanity, tr. G. S. Fraser, (London, The Harvill Press, n. d.), p. 50; cf. p. 75 . Originally published as Man Against Mass Society, (Chicago, Regnery, 1952).

5/bid., p. 176. 
religious thinker, he usually seeks to play a mediating role and to take his stand on experiential grounds which are accessible to the nonbeliever. Is he being inconsistent here? Secondly, he expresses opinions at some places in his work which might seem to be at variance with the resort to the term "creature." For reasons of exposition, it would be useful to begin with an examination of the second point, since it may well shed light on the first.

Anyone who speaks about man as a "creature" is naturally thought to be using a term that is correlative to the conception of God as a "creator." Marcel himself is often enough willing to do so. The trouble is that the latter is a metaphysical notion which carries the freight of the category of cause, and Marcel has told us in a few places that he does not find this category to be particularly helpful in elucidating the ontological meaning of human experience. In his reply to Hartshorne's paper in the Schilpp volume he specifically extends his hesitation to the theological use of the term, and even resists Hartshorne's employment of the term "agent" as applied to God. 6 Yet surely those in the philosophical tradition who have spoken of God as a creator have assumed this to mean that God is the First Cause who brought the world into being out of nothing and that human existence is one of the things which this divine action has caused. Isn't it awkward to avail oneself of the category of "creature" while cavilling at the category of "cause"? Perhaps the right answer is that it is indeed awkward, but that it is not the sort of awkwardness that Marcel's elusive metaphysics would chafe under excessively. Admittedly, the notion of cause he found dubious seems to have been the empiricist's notion of an antecedent invariably connected with a consequent, a notion which found whatever valid application it had in the Marcellian realm of "objects," and was unilluminating in respect to human life. His response to the difficulty was not to seek a more acceptable metaphysical explication of causation, but to approach human existence without reliance on the category.

But if one does not get at the appreciation of creaturehood through a metaphysics of causation, what access to this idea is left? A

6 In The Philosophy of Gabriel Marcel, ed. Paul Arthur Schilpp and Lewis Edwin Hahn, (La Salle, Ill., Open Court, 1984), pp. 368/9. (A volume in Library of Living Philosophers series) 
start at appreciating this might be made if we think of the famous passage in the Phaedo where Socrates renounces any recourse to suicide as morally reprehensible. The grounds upon which he does so are simple and straightforward. Man does not have dominion over his own being and may not dispose of it as he sees fit. We do not belong to ourselves: we belong to the gods and must await their will in the disposition of our lives. Now Socrates never attained the metaphysical conception of creation ex nihilo, but in these utterances he undoubtedly came very close to what Marcel seems to regard as the central significance in the notion of creation: the fact that man's being is not autonomous, that he exists only through participation in an order of reality which surpasses him, and that this participation is spontaneously experienced as a gift.

This will help to answer the first question: does Marcel's emphasis on creaturehood make philosophy dependent on religious belief and therefore compromise its status as thought? Our reply should first record that Marcel would not be inclined to accept any obligation to preserve the status of something called "philosophy" hermetically sealed off from the religious dimension. In his eyes concrete philosophy is a reflection upon integral human experience in an effort to recuperate and express its profoundest intelligibility. It cannot begin with the a priori decision to exclude a religious dimension, or it would betray the task of recognition which is its mission. It begins with human life as it finds it concretely. The conviction of the creaturely character of that life is not an importation from a source alien to experience, but a descriptive interpretation of what reflection discovers in experience itself.

It seems important to note that, while "creaturehood" is an interpretive concept, it is an interpretation precisely of human experience. In this approach, to comprehend man's existence as creaturely is not to subsume it under a more universal category derived from elsewhere, but to achieve an insight into human existence as such. It would, after all, be a matter of small moment and small interest in our study of the behavior of non-human entities to advert to the fact that they are "creatures": our investigation of chemical elements, for example, would proceed on the same lines whatever our view on their creaturely status. But this is not true in the case of man. "Being a creature" affects the way human beings are; it 
is in the comprehension of their specifically human aspects that the concept of creaturehood is required. This could even be put hypothetically: if it is the case that man is a creature in Marcel's sense, then this will affect and be traceable in every aspect of his specifically human existence. The life of reason, intersubjectivity, moral experience, and public and historical existence would all give evidence of this creatureliness. Therefore a philosophical thought that genuinely recuperated human existence would have to recuperate it precisely as creaturely. That is one way of expressing the philosophical import of the traditional theological formula that man is the "image of God."

In the passages which have been quoted, Marcel's thought has arrived at the stage where the condition of creaturehood has become evident and where it can shed an independent light on the experiences upon which he reflects. But it was uncovered originally in the experiences themselves. Which experiences are these? They are the very ones about which his thought perpetually gravitates, the primary experiences of incarnation and communion in which the character of the self as a being-by-participation is manifested. The self which thus comes to light is not an autonomous ego, but an existent whose presence for itself is made possible by the participation within which it arises. The self as participant existent is not the foundation for its own being: it does not confer the content of its participation upon itself.

Fundamental among these participations is the experience of embodied presence to the world which Marcel calls "incarnation." His absorption with the theme of incarnation was initially aroused by his efforts to overcome the epistemological difficulties of Cartesian subjectivism. But it is easy to overlook that his aphorism "I am my body" presupposes that the experience of incarnation is the experience of an "I": it is not simply a formula for embodiment, but the epitomizing of an embodied selfhood. "Here I am, what luck!" is the way that Marcel conveys the "exclamatory awareness" of existence which emerges in incarnation. 7 There is no way in which a self in this moment of astonishment can regard itself as the author of its own being - its natural tendency is to assume that it is the beneficiary of an

7The Mystery of Being, vol. I, pp. 90/1. 
inexplicable gift.

Incarnation is the first level in the progressive cognizance of the gift character in my self-conscious existence. 8 This character is confirmed and enlarged at the level of communion, since the presence of the thou is not something which it is within my power to confer upon myself: it is a free bestowal which founds my own being in a new mode of self-presence. In its ultimate depth, the orientation to the co-presence of the other which characterizes all self-presence is revealed through the exigence for the fullness of presence which Marcel calls "being." This exigence cannot be regarded as a mere accidental supplement to a self whose essential significance can be comprehended apart from it. Rather, the ontological exigence is also a form of participation. As such it is the foundation for a new and unique level of intelligible self-presence. Nor is there any way in which some other department of the self can claim to assess the validity of the exigence for plenitude, for this exigence establishes the self in a realm transcendent to the abstract order where the notion of "validity" has its proper application.9

Paradoxically, this exigence is a participation precisely insofar as it is a need, and this provides a strong warrant for calling Marcel's thought in the last analysis "Augustinian." For at the deepest level of concreteness in the human existent, the self is experienced as a yearning, a lack which is oriented towards a fullness. Obviously he does not intend this to be a credal pronouncement; it is a phenomenological uncovering of a truth about human existence as such and thus still occupies common ground with the reflective nonbeliever.

To generalize: whatever is specifically human about me whatever is grasped as comprising my uniquely human way of beingin-the-world - turns out to be a participation in what is beyond me. In this light it is easy to understand the monumental discovery of Socrates and Plato as a step on the road to the recognition of creaturehood. Reason as such, they saw, is not something individual and isolated, but a participation in ... a participation in an order of

8The Mystery of Being, vol. II, p. 173.

9On the ontological exigence, see The Mystery of Being, vol. II, ch. 3. 
intelligibility which has precedence over the individual. The individual is actually constituted as rational by the participation in this transcendent order. For even as reasoner, I am not autonomous: I do not belong to myself. To say "I am rational" is ipso facto to say that my thinking is a participation in a "common." A private reason, as Heraclitus saw, is a nonsense. And for the benefit of moderns and post-moderns, one might add that a collective private reason is in no better case, so that a "consensus" theory of truth is also a nonsense.

The historical process of self-understanding which this discovery originated blended with the influence of Christian faith and metaphysics to form a public and political reality which has carried with it an articulated conception of the God who answers to human longing. Intersubjectivity has borne its testimony to the being which answers to the obscure exigence which arises within the human subject, and the actual course of history has been shaped by this intersubjective self-understanding. This is a fact of central importance, since, as Marcel says, "man depends, to a very great degree, on the idea he has of himself ..." 10

Now the affirmation of my creaturehood is not accomplished by an abstract thought or by a neutral spectator reason. Its vehicle is the fully concrete human life which is at the same time the target of the affirmation. Hence whatever distorts or degrades this life in the concrete makes the affirmation of transcendence impossible or difficult; conversely, whatever makes this affirmation impossible degrades the concrete life of man. Much of Marcel's social thought is inspired by his contemplation of the human impoverishment which has ensued upon the loss of the social sense of creaturehood, a loss which seemed to justify the fear that the very idea of man is "decomposing before our eyes." 11

Far from being the insult to my freedom and dignity which secular humanists have declared it to be, the affirmation of my creaturehood looks like the sole basis upon which this dignity can be preserved. Consider the alternative to the acknowledgement of

10Men Against Humanity, p. 14.

11 /bid., p. 134. 
creaturehood. In my denial I will either be tempted to claim complete independence for the ego, or I will be tempted to understand it as a product of natural processes, a negligible epiphenomenon whose significance an adequately developed science could discountenance altogether. I will, as it were, either deify the self or nullify it, and so lose contact with my proper humanity.

In point of fact the two alternatives tend to have similar consequences in practice. For whether I exalt the ego or debase it in theory, my empirical ego must in practice live out its life without reference to any imperium beyond itself. As Marcel says, the more man treats himself as the result of purely natural causes,

the more he arrogates to himself the right of absolute sovereignty in all that concerns the ordering of his personal conduct. The more he is theoretically humiliated by a materialist philosophy which claims to deny any special identity in himself or his actions, the more does he actually develop a practical pride which impels him to deny the existence of any human order to which he might owe obedience. 12

Such an ego appears to lack all focus except its succession of desires and fears, and at best will regard itself as a center of power for the effectuation of motives based upon them. Inevitably it will be drawn into systematic conflict with other egos understood as competing centers of power. In the political order it will be capable of forming alliances with like-minded others, but it can rise to no higher conception of the political order than as an arrangement which permits maximum satisfaction to competing centers of power. To such a pass our modern democratic liberal state now seems to have come.

It is by no means certain, however, that a political order resting on such an idea of man is on a very secure basis. It may well be living on the capital of the past. We have grown accustomed in our day to hear that democracy upholds the "rights of the person," and the assertion of such rights has expanded hyperbolically in recent years. But the idea of person is certainly historically connected with the acknowledgement of creaturehood, and it highly questionable that it

${ }^{12}$ Homo Viator, p. 95. 
is viable apart from it. Marcel was of the opinion over forty years ago that the idea of person is today without roots, that it is a survival. We ought to admit, he says, that if the idea of person is still capable of generating any respect, "it is only to the degree in which the notion profits from the aura which surrounds the notion of a creature formed in the image of his Creator." 13 As currently used, it is at risk of being just a weapon in the game of power played among egos which recognize only their own desires as normative in their behavior.

At the time of his major writings Marcel had before his eyes the examples of the two totalitarianisms to demonstrate what havoc could be wreaked on flesh-and-blood human beings by a public power with a false idea of man. These evils may now be behind us, but the social and cultural despoliation which Marcel portrayed in western society is surely deeper and more widespread than what he had to contemplate, and it too occurs because a public sphere imposes a false idea of man upon private lives. Marcel only had cause to deplore the "abominable propaganda" 14 which promoted abortion, while we in our own day witness the full actuality of a governmentsponsored slaughter carried on in the name of human rights. But could this and other outrages ever have come to pass except against the background of a relentless desacralization of human life brought about by the public powers which shape our daily existence? It cannot be without consequence that from earliest infancy the communication and entertainment industries overwhelm the human psyche with an indiscriminate succession of images, a succession to which of late years the freakish and depraved contribute an increasingly generous share. By displaying the equality of all desires, they convey the meaninglessness of all. And can they be wrong? Are they not backed by the authority of an educational establishment which teaches the relativism of value and truth, and indeed, at its upper and more fashionable levels, even proposes the malleability of the language text in which it teaches this? In such an atmosphere, even the "liberty" upon which the West plumes itself becomes a doubtful adornment: for if we are worthless, what does it matter that

13Men Against Humanity, p. 174.

14 Homo Viator, p. 89. 
we are free? ${ }^{15}$

It is as if much of modern life has conspired to adduce a kind of forgetfulness of their own humanity in the minds of those who breathe its air. When they do think about it, Marcel remarks that there is a danger that the materialist outlook which is presumed to account for our "progress" has been adopted by the man in the street to such an extent that it has erected a wall between his own best experience of life and his thought about it. 16 Marcel's philosophy wants to breach that wall. It is his aim to bring us back to the experiences in which our creaturely existence, in all its unique misery and grandeur, is brought to recognition. His reflections on fidelity, hope, and love, his explorations of incarnation, value, freedom, death, testimony, his entire dramatic work, his social reflections, such as the essay on the family which now seems so prescient, have no other goal.

Marcel's dedicated and successful pursuit of this goal over five decades and in a truly inimitable manner was an extraordinary achievement. The task he set himself was not easy and it has become harder in our time. For we think with what we are, and to the extent that the daily social scene in which we all live out our existence exhibits the spectacle of desecration, the resources to affirm the true character of human life are weakened and depleted. Under these circumstances, we can understand why Marcel says that the philosopher's task will always be that of "recollection": to call us back to that sacred center where our creaturehood remains inviolate, and where, by opening ourselves to a presence immeasurably beyond us, we are open to all our fellow-creatures.

Fordham University

KENNETH T. GALLAGHER

15Marcel's belief that the meaning of freedom could only be seen in relation to a transcendent order (Men Against Humanity, p. 184) has an interesting, rather Thomistic counterpart in John Paul II's recent encyclical Veritatis Splendor.

16 Tragic Wisdom and Beyond, p. 108. 